\title{
Effects of oxytocin, prostaglandin and phenylbutazone on uterine clearance of radiocolloid
}

\author{
Michelle M. LeBlanc \\ College of Veterinary Medicine, University of Florida, USA
}

\begin{abstract}
Summary
An inability to clear the uterine lumen quickly of the inflammatory by-products of breeding is a major cause of infertility. Mares with this condition may be diagnosed by scintigraphy, as can the effects of drugs on uterine clearance. Administration of oxytocin or cloprostenol, a prostaglandin analog, improves uterine clearance, whereas, phenylbutazone, a cyclooxygenase inhibitor, delays uterine clearance of a radiocolloid. Inhibition of uterine clearance by phenylbutazone can be overridden by administration of oxytocin indicating the presence of a direct effect of oxytocin in the mare.
\end{abstract}

keywords: $\quad$ horse, uterine clearance, oxytocin, phenylbutazone, prostaglandin

\begin{abstract}
Die Wirkung von Oxytocin, Prostaglandin und Phenylbutazon auf die uterine Clearance von Radiokolloiden
Eine der bedeutsamsten Infertilitätsursachen bei der Stute stellt die Unfähigkeit des Uterus dar, die Nebenprodukte der durch die Belegung hervorgerufenen Entzündung schnell zu entfernen. Diese Störungen der Clearancemechanismen können mit Hilfe der Szintigraphie diagnostiziert werden. Diese Methode dient auch dazu, den Effekt von Uterotonika zu untersuchen. Die Applikation von Oxytocin oder Cloprostenol, einem Prostaglandinanalogon, unterstützt die uterinen Clearancemechanismen, während Phenylbutazon, ein Cyclooxygenasehemmer, die Eliminierung von Radiokolloiden verzögert. Die durch Phenyibutazon hervorgerufene Hemmung der uterinen Clearance kann durch Oxytocin-Gaben unterdrückt werden. Der Effekt von Oxytocin auf die Uteruskontraktionen der Stute scheint daher direkt, d. h. unabhängig vom Prostaglandin, oder Ausdruck einer synergistischen Wirkung mit Prostaglandin zu sein.
\end{abstract}

Schlüsselwörter: Pferd, uterine Clearance, Oxytocin, Phenylbutazon, Prostaglandin

\begin{abstract}
Persistent mating-induced endometritis commonly causes infertility in pluriparous mares greater than 14 years of age and in young mares with cervical incompetence. Mares susceptible to this condition are unable to physically clear the transient endometritis that results from intrauterine depostion of semen (Kotilainen et al. 1994; Troedsson et al. 1995) within the required time. The uterus must be free of inflammation by day 5 after ovulation when the embryo descends from the oviduct or the embryo may not survive. The cause of the persistent mating-induced endometritis is not known, however, an abnormality in myoelectrical activity (Troedsson et al. 1993), poor perineal conformation (LeBlanc MM, unpublished data) and overstretching of nerves located in the broad ligament (Johnson R. Personal communication) have been implicated. Treatment has been directed at rapid removal of the inflammatory debris within the uterine lumen by uterine lavage and administration of drugs that induce uterine contractions. As uterine contrac tions appear to be controlled hormonally in women and laboratory animals by the synergistic action of oxytocin and prostaglandin (Fuches 1987), both hormones have been used to enhance uterine clearance in the mare. There are differences, though, between the drugs in their ability to clear the uterine lumen and in uterine contraction time. In addition, prostaglandin and its analogs have different pharmacological properties.
\end{abstract}

Scintigraphy, a nuclear medicine technique, has been used to study the effect of drugs on uterine clearance of fluid and to classify mares as reproductively normal or susceptible to endometritis (LeBlanc et al. 1994a, LeBlanc et al. 1994b). In this technique, $10 \mathrm{mCi}$ of Technetium $99 \mathrm{~m}$-albumin colloid is infused into the uterus during estrus ( $\mathrm{Neu}$ wirth et al. 1994) and the amount of radiocolloid expelled over time is measured. Reproductively normal mares clear $>50 \%$ of the radiocolloid within 2 hrs of its infusion into the uterus, whereas, mares susceptible to persistent mating-induced endometritis clear negligible amounts (LeBlanc et al. 1994a). Administration of 20 i.u. of oxytocin induces rapid clearance of radiocolloid in both susceptible and control mares (LeBlanc et al. 1994b). All mares cleared $>90 \%$ of the radiocolloid within 30 minutes of its injection (Figure 1). When prostaglandin and its analogs, cloprostenol and fenprostalene, were given to both groups of mares, the results were not as dramatic (Figure 2; Combs et al. 1996). Mares cleared the radiocolloid slowly and not all mares responded to prostaglandin (5 mg IM) and fenprostalene (250 mcg $\mathrm{SQ}$ ). Mares given cloprostenol (500 mog IM) cleared a mean of $65 \%$ of the radiocolloid by 60 minutes after infusion and $78 \%$ by two hours, significantly slower than that induced by oxytocin.

Although uterine clearance of radiocolloid is slower after prostaglandin administration, prostaglandin does cause the 
uterine to contract for a longer period of time than oxytocin. Prostaglandin produces a rise in intrauterine pressure within 10 minutes of administration (Goddard and Allen 1985) and contractions last for up to 5 hours (Troedsson et al. 1995). Oxytocin induces a more immediate response, within 60 seconds, but contractions last for only 40 minutes (Cadario et al. 1995; Troedsson et al. 1995).

Both oxytocin and cloprostenol are useful clinically. Oxytocin has been given alone or in combination with uterine lavage or antibiotics after breeding to clear the uterus of fluid that has accumulated in the uterine lumen. There are many scientific and anecdotal reports of increased pregnancy rates following its use (Pycock 1994; LeBlanc 1994; Rasch et al. 1996) This author prefers to treat susceptible mares between four and eight hours after breeding as the sperm will be in the oviduct by two hours and neutrophil numbers will reach maximum levels in the uterine lumen by 8 hours after breeding (Katila 1995). If neutrophils remain in the uterine lumen for a prolonged time, the endometritis may be exacerbated as degranulated neutrophils will recruit more neutrophils, $\lg G$ and proteins to the site.

Cloprostenol appears to be beneficial in mares that have lymphatic stasis. Lymphatics drain particulate matter from the uterine lumen and reabsorb the intramural fluid that accumulates within the uterine wall during estrus. Uterine

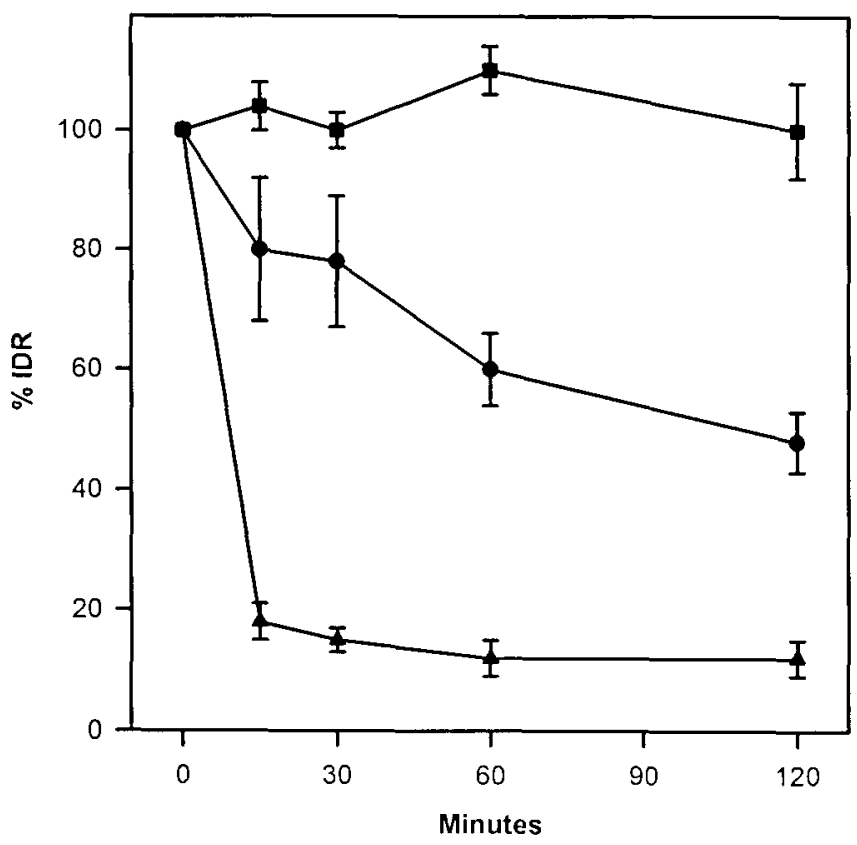

Fig. 1: Mean percentage \pm sem of the initial dose of $99 \mathrm{mT} \mathrm{C}-\mu \mathrm{AA}$ that remained in the uterus after infusion during estrus in mares susceptible to endometritis ( $\boldsymbol{\square}$ ) and reproductively normal mares (-) compared to percentage that remained in the uterus after 20 iu of oxytocin i.v. (A),

Mittlerer Prozentsatz (mit Standardabweichung) der initialen Radiokolloiddosis, die im Uterus nach Infusion im Östrus bei endometritisempfänglichen Stuten ( normalen Stuten $(\bullet)$ verblieben ist, verglichen mit dem Prozentsatz, der nach 20 IE Oxytocin i.v. im Uterus verbliebenen ist. lymphatics drain dorsally into lymphatic vessels in the broad ligaments which, in turn, drain into the iliac and aortic lymph nodes located lateral to the aorta (Guyton 1991). Lymphatic vessels do not contain smooth muscle and therefore, must rely on uterine contractions to push the lymph dorsally. Mares with lymphatic stasis tend to accumulate fluid within the uterine wall and uterine lumen, have lymphatic cysts visible on ultrasound examination, and are frequently infertile. Mares with lymphatic lacunae and uterine cysts are unable to reabsorb an infusion of India ink, a carbon compound that has an affinity for the lymphatics, during diestrus. These mares also secrete fluid back into the lumen which contained neutrophils, lymphocytes and macrophages (LeBlanc et al. 1995). Reproductively normal mares, on the other hand, reabsorb all of the ink. The ink is engulfed by macrophages, lymphocyes and neutrophils in the endometrium, which enter the uterine lymphatics and are then transported to the iliac and aortic lymph nodes.

Prolonging uterine contractions by administering cloprostenol or by injecting oxytocin frequently may improve fertility in mares with lymphatic status. A combined treatment of uterine lavage and oxytocin between 4 and 8 hours after

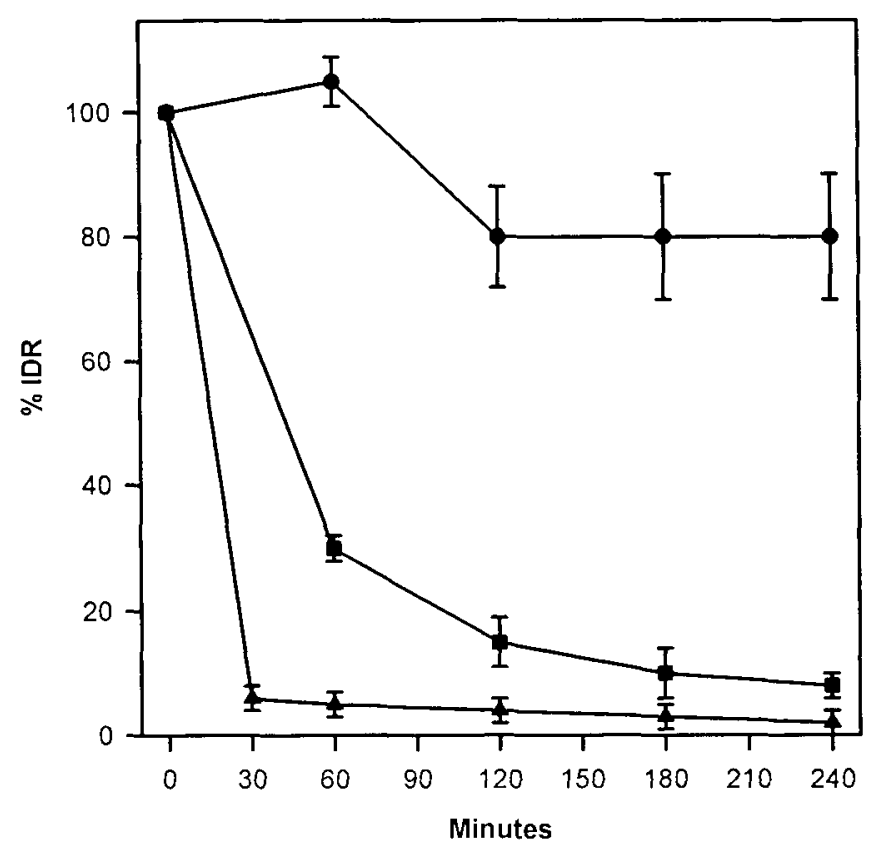

Fig. 2: Mean percentage \pm sem of the initial dose of ${ }^{99 m} T c-\mu A A$ that remained in the uterus after infusion during estrus in mares susceptible to endometritis (-) compared to percentage that remained in the uterus of these same mares after $500 \mathrm{\mu g}$ of cloprostenol i.m. (口) and after $20 \mathrm{iu}$ of oxytocin i.v. (A). Only one experiment was conducted during each estrus.

Mittlerer Prozentsatz (mit Standardabweichung) der initialen Radiokolloiddosis, die bei östrischen endometritis anfälligen Stuten $(\bullet)$ im Uterus nach Infusion verblieben ist, im Vergleich mit dem Prozentsatz, der bei denselben Stuten im Uterus verblieben ist nach 500 $\mathrm{\mu g}$ Cloprostenol i.m. (口) und nach $20 \mathrm{IE}$ Oxytocin i.v. (A). Pro Östrus wurde nur ein Versuch durchgeführt. 
insemination and administration of cloprostenol at 12 and 24 hours has been beneficial in eight mares that had persistent mating-induced endometritis and lymphatic stasis (which likely contributes to the delay in uterine clearance; LeBlanc, unpublished observations 1997). All mares conceived and, to date, only one mare has aborted (at 8 months). The uterine lavage is performed to remove pus and debris from the uterine lumen, oxytocin enhances immediate emptying and cloprostenol produces prolonged and sustained contractions that may be helpful in moving lymph out of the uterine wall.

The non-steroidal antiinflammatory drug, phenylbutazone, is frequently given to broodmares in North America to lessen the clinical signs of laminitis. It inhibits prostaglandin synthesis by irreversibly binding to the enzyme cyclooxygenase. It may also inhibit uterine clearance in reproductively normal mares. When $2 \mathrm{gm}$ of phenylbutazone were given intravenously 3.5 hours before radiocolloid was infused into the uterus of ten reproductively normal mares during estrus, mares cleared only $23.5 \% \pm 9.8 \%$ (mean + SEM) during a 2 hour study. These same mares cleared $60 \% \pm$ $4 \%$ when no drug was given. Oxytocin overrode the effect of phenylbutazone on uterine clearance. When the mares treated with phenylbutazone were given 20 i.u. of oxytocin immediately after the first scintigraphy reading, all mares cleared $>90 \%$ of the radiocolloid by 30 minutes (Cadario et al. 1995). Phenylbutazone also inhibited prostaglandin FM release when given alone or in combination with oxytocin. So it appears that uterine contractions in the mare may be induced by oxytocin independent of prostaglandin or by the synergistic action of oxytocin and prostaglandin.

\section{References}

Cadario, Maria; Thatcher, Marie-Joelle and Michelle LeBlanc (1995): Relationship between prostaglandin and uterine clearance of radiocolloid in the mare. Biol Reprod Mono 1, 495-500.

Cadario. Maria (1997): Uterine Clearance Mechanisms in the Mare: Hormonal Interactions. Masters of Science Thesis, University of Florida, USA.

Combs, G. B.; LeBlanc, Michelle; Neuwirth, Lisa and T. Q. Tran (1996): Effects of prostaglandin $F_{2 x}$, cloprostenol and fenprostalene on uterine clearance of radiocolloid in the mare. Theriogenology 45 , 1449-1455.

Fuches, Anna Ritta (1987): Prostaglandin $F_{L u}$ and oxytocin interaction in ovarian and uterine function. J Steroid Biochem 27, 1073-1080.

Goddard, P.J., and W.E. Allen (1985): Genital tract pressures in mares II. Changes induced by oxytocin and prostaglandin $F_{2 u}$. Theriogenology 24, 35-44.

Guyton, A. C. (1991): The lymphatic system. In: Textbook of Medical Physiology, 8th ed. Philadelphia: W. B. Saunders Co.; 180-184.

Katila, Terttu (1995): Onset and duration of uterine inflammatory response of mares after insemination with fresh semen. Biol Reprod Mono 1, 515-517
Kotilainen, T.; Huhtinen, M. and Terttu Katila (1994): Sperm induced leukocytosis in the equine uterus. Theriogenology 41, 629-636.

Neuwirth, Lisa; LeBlanc, Michelle; Asbury, A. C.; Tran, T. Q.; Mauragis, Danielie and Elisabeth Klapstein (1994) : Uterine clearance of radiocolloid in mares potentially susceptible and resistant to endometritis. Vet Radiol Ultrasound 36, 64-68.

LeBlanc, Michelle; Neuwith, Lisa; Asbury, A. C.; Tran, T. Q.; Mauragis, Danielle and Elisabeth Klapstein (1994a): Scintigraphic measurement of uterine clearance in normal mares and mares with recurrent endometritis. Equine vet J 26, 109-113.

LeBlanc, Michelle; Neuwirth, Lisa; Mauragis, Danielle; Klapstein, Elisabeth and T. Q. Tran (1994b): Oxytocin enhances clearance of radiocolloid from the uterine lumen of reproductively normal and infertile mares. Equine vet $\mathrm{j} 26,279-282$.

LeBlanc, Michelle (1994): Oxytocin - the new wonder drug for treat ment of endometritis? Equine vet Ed 6, 39-43.

LeBlanc, Michelle; Johnson, R. D.; Caldemood Mays, Maron and Claudia Valderrama (1995): Lymphatic clearance of India ink in reproductively normal mares and mares susceptible to endometritis. Biol Reprod Mono 1, 501-506.

Pycock, J.F. (1994): Assessment of oxytocin and intrauterine antibiotics on intrauterine fluid and pregnancy rates in the mare. Proc Am Assoc Equine Pract 19-20.

Rasch, Kathrin; Schoon, H. A.; Sieme, H. and E. Klug (1996): Histomorphological endometrial status and infiuence of oxytocin on the uterine drainage and pregnancy rate in mares. Equine vet $\mathrm{J} 28$, 455-460.

Troedsson, M.H.T. and I. K. M. Liu (1991): Uterine clearance of nonantigentic markers $\left(\mathrm{Cr}^{51}\right)$ in response to a bacterial challenge in mares potentially susceptible and resistant to chronic uterine infection. J. Reprod Fertil Suppl 44, 283-288.

Troedsson, M.H.T.: Liu, I.K.M.; Ing, Michelle; Pascoe, J., and M. Thurmond (1993): Multiple site electromyography recordings of uterine activity following an intrauterine bacterial challenge in mares susceptible and resistant to chronic uterine infection. I Reprod Fertil $99,307-313$.

Troedsson, M.H. T.; Liu, I. K. M.; Ing, Michelle and J. Pascoe (1995): Smooth muscle electrical activity in the oviduct, and the effect of oxytocin, prostaglandin $F_{2 x}$, and prostaglandin $E_{2}$ on the myometrium and the oviduct of the cycling mare. Biol Reprod Mono 1 , $475-488$.

Prot. Michelle M. LeBlanc

College of Veterinary Medicine

University of Florida

Gainesville, FL 32610 USA

Tel: 001-352-392-4700

Fax: 001-352-392-8269

email:Leblanc.vetmed3@mail.health.ufl.edu 